\title{
svabhāva に對する一考察
}

\section{一三十頌安慧釋の範圍內に於て——}

\section{北川秀 則}

parikalpita-svabhāva (遍計所執性)，paratantra-svabhāva (依他起性)，pariniṣpanna-svabhāva（圓成實性）が唯識哲學に於ける最も重要な術語であるととは論 を俟たない。本稿はこれらの術語中に含まれる svabhāva といら語の概念規定を その目的とするものである。但し筆者は，乙れを唯識關係文獻の全體に亘つて論 ずるだけの知識をもたない。そてで今はただ三十頌並にてれに對する安慧釋の範 圍內で論ずることにしよう。

まずとれらの術語が合成語であるととに着目したい。三十頌安慧釋には，乙れ らの合成語が karmadhāraya として理解されている場合と, bahuvrīhi として 理解されている場合とが存する。この中 karmadhāraya として理解されていた ことを示す例を擧げれば次の如くである。

(1) sūtreșu hi trayaḥ svabhāvā uktāḥ parikalpitaḥ paratantraḥ pariniṣ. pannaś ca/ (p. 39. 5 ff.)

(2) parikalpitena svabhāvena (p. 40.7)

(3) parikalpitah svabhävaḥ (p. 41. 14)

(4) paratantraḥ svabhāvaḥ (p. 40. 22)

(5) parinișpanne svabhāve (p. 40. 23)

(6) pariniṣpannaḥ svabhāvaḥ (p. 41. 21; p. 41. 22)

以上は一見して明瞭なものを例示的に示したにすぎず，てのほかにもてれらの合 成語が karmadhāraya として理解されていたてとを直接間接に示す籄處は, Lévi 版39頁以降の諸頁中隨處に見出される。次に bahuvihi として理解されて いたととを明確に示す例としては，

(7) yad vastu vikalpa-viṣayas tad yasmāt sattâbhāvān na vidyate tasmāt tad vastu parikalpita-svabhāvam eva/ na hetu-pratyaya-pratipadyasvabhāvam/ (p. 39. 13) 
が存する。svabhāva は元來男性名詞であるが，この例に於ては tad vastu に合 わせて parikalpita-svabhāvam, hetu-pratyaya-pratipadya-svabhāvam と中性 の語尾が用いられている。 hetu-pratyaya-pratipadya-svabhāva とは paratantra-svabhāva のてとであるから，上の例は， parikalpita-svabhāva と paratantra-svabhāva とが bahuvrīhi の合成語として理解されていたてとをはつきりと 示していると言えよう。なお pariniṣpanna-svabhāva についてはてれが bahuvrīhi として理解されていたてとを明確に示す例は見當らない。及，paratantrasvabhāvaについても，てれが bahuvrīhi として理解せられていたととは，hetupratyaya-pratipadya-svabhāva といら語を通じて間接に了解せられるのみであ る。そこで以下最も資料の揄つている parikalpita-svabhāva を取り上げて論じ たい。

さて parikalpita-svabhāva が karmadhāraya と bahuvrīhi の兩方に用いら れているということは，との語が「分別せられた自性（論述の便宜上，以下暫く svabhāva は「自性」と譯すととにする)」と分別せられた自性をもてるもの」といら 二つの意味に用いられているといらととを意味する。しかしながら，はじめに述

（1）このほか bahuvrīhi と解する方が自然であると考えられる場合として例えば次の 如きものを舉げるととが出來る。

evam ca sarvam vijñeyam parikalpita-svabhãvatvād vastuto na vidyate, vijñānaṃ punaḥ pratītyasamutpannatvād dravyato 'stîty abhyupeyam/ (p. 16. $15 \mathrm{ff}$.)

こてでは, parikalpita-svabhāva が bahuvrīhi であるととは, 引用交(7)の場合の ように格語尾によつて確認するととは出來ない。しかしながら， sarvạ vijñeyam parikalpita-svabhāvatvād vastuto na vidyate とは, 「一切の認識對象は, parikalpita-svabhāva であるから, 存在しない（直譯：一切の認識對象は, 〔その有 する】 parikalpita-svabhāvatva の故に，存在しない)」というととであるから， parikalpita-svabhāva といら合成語全體としては存在性 (existence) をあらわして いるのではなく存在者 (existent)を西らわしていると理解すべきである。認識對象 は存在者（二存在性を有するもの）ではあっても存在性ではないからである。從つ て svabhāva を「自己の存在性」といらょらな意味に解するならば， parikalpitasvabhāva は bahuvrīhi として理解するのが自然である。（但し本稿を最後まで讀 まれた讀者は, とてでも parikalpita-svabhāva が bahuvrīhi と karmadhāraya

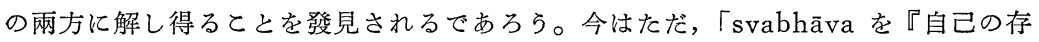
在性』というょうな意味（ての意味は普通には svabhāva の最も基本的な意味であ る）飞解するならば」といら條件の下に, 議論の出發點に於て bahuvrīhi 飞解した 方が自然と考えられる parikalpita-svabhāva の例を舉げたにすきない。) 
べたよらに, parikalpita-svabhāvaは唯識哲學に於ける最も重要な術語の一つで あるから，との語によつてあらわされるものが，或る時は分別せられた自性であ

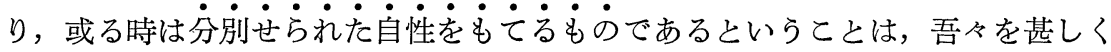
當惑せしめる。しかし，それでもなお次のように考える餘地があれば，吾ふとし ても納得出來ないわけではない。郎ち karmadhāraya としての parikalpitasvabhāva と bahuvrīhi としての parikalpita-svabhāva とは全く別個のものを 指さす別個の單語であり，この中基本的術語であるのは，例苀ば，前者であつて 後者ではない。三十頌安慧釋全體を通じ前者を parikalpita-svabhāvah（但し主 格の場合。その他の格の場合はそれぞれ parikalpitạ svabhāvam, parikalpitena svabhāvena etc. とする)，後者を parikalpita-svabhāva-vat と書き改め，それぞれに 全く別個のものを指ささせ，それで全體の意味が通じればいいではないか，と。 しかしながらてのよらな試みは, karmadhāraya としての parikalpita-svabhāva と bahuvrīhi としての parikalpita-svabhāva とが全く同一物を指さしている事 例が存するてとによつて阻止せられる。そしてその事例とは次の如くである。

(8) yena yena vikalpena yad yad vastu vikalpyate/ parikalpita evâsau svabhāvo na sa vidyate//

これは三十頌の第20偈であるが，さきに擧げた(7)の引用文は實にとの偈文に對す る安慧釋の一部であつたのである。まず偈文の方から檢討するに，この偈文の 2 、 行目中程の asau が1行目の yad yad vastu を受けていることは言らまでもな い。そうなると，ことでは yad yad vastu=asau=svabhävah= parikalpitah といら等式が成立つととになる。つまりととでは, parikalpita-svabhāva は karmadhāraya として了解せられており, yad yad vastu がそれによつて指ささ れているのである。ところがこの部分に對する安慧釋，節ちさきに擧げた引用文 (7)に於ては，parikalpita-svabhāva ははつきりと bahuvrīhi の合成語であつた。 師ちそてでは, parikalpita-svabhāva は中性形の tad vastu を受けているため にそれに合せて中性語尾をとつていたのである。とてろがこてで泩意すべきは， この tad vastu は(7)の冒頭の yad vastu を受けており，ての yad vastu は更 亿遡つて偈文 (郎ち引用文(8)) 中の yad yad vastu を受けているといらととであ る。そらなると今度は, $\mathrm{yad}$ yad vastu=yad vastu=tad vastu= parikalpita-

（2）yad yad vastu が中性形であるにも拘らず asau が男性形であるのは，次に來る svabhāva が男性形であるからである。 
svabhāvam といら等式が成立つととになる。つまりここでは bahuvrīhi の合成 語である parikalpita-svabhāva が yad yad vastu を指さしているわけである。 てのように, parikalpita-svabhāva といら語は一方では karmadhāraya として 理解せられ，他方では bahuvrīhi として用いられているにも拘らず，そのいずれ の場合にも同一のもの（郎ち yad yad vastu）を指さしているという事例が存す る以上, karmadhāraya としての parikalpita-svabhāva と bahuvrīhi として の parikalpita-svabhāva を全く別箇のものを指さす別箇の語と考えるととは許 されない。

ところがそうなると，

(分別せられた自性)=(分別せられた自性をもてるもの)

といら等式の成立することが至上命令となる。何となれば，ての等式が成立しな ければ，唯識哲學に於ける最も重要な術語の一つであり，從つてその概念內容が 明確であるべき parikalpita-svabhāva といら語が, karmadhāraya と bahuvrīhi の兩方に用いられながら而も同一物を指さしているという事實を說明するてとが 出來ないからである。とてろが一般的に言つて，

$\mathrm{X} \vDash(\mathrm{X}$ をとるもの)

というのが吾々の常識である。例えば,

$$
\text { danḍa } \neq \text { daṇdin gotva fgo }
$$

である。daṇda は杖であり物であるが, daṇ̣in は杖をもてるもの, 郎ち人間で ある。又, gotva 郎ち牛性は jāti であるが, gotva をもてるものは牛であり dravya である。然るに今は,

（分別せられた自性）＝(分別せられた自性をもてるもの）

という等式の成立するてとが至上命令として要求せられている。そてでてれをど のように解決すべきか，てれが本稿の目指すところなのである。

まず,

(分別せられた X) =(分別せられたXをもてるもの)

という等式を考えて見よう。そしてXに svabhāva といらサンスクリット語の意 味し得る範圍內でどらいら概念をはめこめばての等式が滿足されるかを考えて見 たい。

なず性」といら概念を入れて見よら。なおててで「性」とは「牲性」「無常 性」という時の「性」, 即ち gotva 或は anityatā といら時の tva 或は tā によ つてあらわされる意味內容と同じ意味內容をもつた概念として理解するととにす 
る。さてそうすると，「分別されたX」とは「分別された性」といらことになり， てれを牛について言えば「分別された gotva (牛性)」，馬について言えば「分別 された aśvatva(馬性)」いとうととになる。つまり牛なり馬なりに存する gotva なり aśvatva なりが分別せられたものである時，その gotva なり aśvatva なり が「分別せられたX」なのである。一方「分別せられたXをもてるもの」とは 「分別せられた性をもてるもの」といらてとになる。從つてての場合は，牛なり 馬なりには gotva や aśvatva は存しないにも拘らず，てれらが存すると分別さ れている場合，その牛なり馬なりが「分別せられたXをもてるもの」となるわけ である。換言すれば，「分別されたX」が gotva や aśvatva であるのに對し， 「分別されたXをもてるもの」は牛や馬なのである。從つて「性」といら概念を はめてむてとによつては，

(分別されたX) $=($ 分別されたXをもてるもの) といら等式は滿足されない。

それでは一體どらいら概念を「X」にはめこめばよいか。筆者はこてで「體」 という概念をはめこむととを提案したい。何となれば，「X」に「體」という概 念をはめとむと，「分別されたX」は「分別された體」となり，「分別されたXを もてるもの」は「分別された體をもてるもの」となるが，てれをさきの牛や馬に あてはめて考光ると次のようになるからである。つまり牛なり馬なりが實際には 存しないにも拘らずてれが存在すると分別されている場合，ほかならぬその牛な り馬なりが「分別された體」であるが，ての場合「分別された體をもてるもの」 は，これまたその牛なり馬なりを措いて他には存しないからである。從つててて に

(分別せられた體) $=($ 分別せられた體をもてるもの) という等式が成立し，

(分別せられたX) =(分別せられたXをもてるもの) といら等式は滿足されるわけで㐫る。

なおここで，筆者の考えている「體」といら概念をもら少しはつきりさせて見た い。假にてれを英譯すると，form が比較的近いと考光られる。例えば an animal having the form of a cow, 或は an animal in the form of a cow といら時の form がてれである。この場合 of は同格關係をあらわす of であるから「とい ら」と譯せばはつきりする。つまり上記の英交は「牛といら form をもつた動 物」或は「牛という form に於ける動物」という意味になるのである。從つてて 
の場合の form は, material に對する抽象的な外枠としての form ではなく， 寧ろ material をも含めての具體的な form（牛や馬について言えば，その外形だけ でなく，血や肉や本能等をも含めたもの）である。筆者が「體」といら言葉で考えて いるのはこらいら意味での form である。

サンスクリットでこの概念をあらわす語に rūpa と a tman とがある。例えば go-rūpa-paśu, gavâtmaka-paśu といら表現中の rūpa 或は ātman がそれであ る。つまりとれら二つの表現はいずれも「牛といら體をもつた動物」と譯すとと が出來るのである（もつと思いきつて意譯すれば「牛という動物」と譯してもよい。）さ て三十頌安慧釋にも, svabhāva がこの意味での rūpa 或は ātman として理解 されていたてとを明瞭に示している箇處が存する。まず前者の例をあげるに，

(9) tasmāt sarvam idam vikalpa-mātram eva tad-arthasya parikalpitarūpatvāt/ (p. 39. 17)

の末尾の parikalpita-rūpatvāt の中の rūpa がこれである。引用文(9)は，テキ ストでは，引用交(7)のすぐ後につづいているので（間に約二行他の交章が挿入されて いるが，てれは無視してょい)，(7)の中の言葉は文脈上(9)の中の言葉によつて受け つがれている。そてで今(7)と(9)の引用文を一括して檢討しょう。まず(9)の tadarthasya はその少し前の vikalpa-mātram の vikalpa を受けているから, tadarthasya は vikalpârthasya である。そしてての vikalpârthasya は更に遡れば (7)の yad vastu vikalpa-viṣayas を受けている。ところが一方，(9)の末尾の parikalpita-rūpatvāt の parikalpita-rūpa は, (7)の parikalpita-svabhāvam を受 けている。とてろがそうなると，同一のもの（tad-artha=vikalpa-vișaya）が，(7) では parikalpita-svabhāva, (9)では parikalpita-rūpa として說明されているて とになり， svabhāva=rūpa といら理解がこてで前提されていたてとは明らかで ある。次に svabhāva=ātman として理解されていたととを示す例としては，

(10) tat punah kiṃ-svabhāvam ity āha/ mananâtmakam/ (p. 22. 29) を擧げるととが出來よう。「それは刃何を svabhāva としているのか」という問 いに對し，「思量を ātman としている」と答えているのであるから，ててで svabhāva=ātman といら理解が前提されていたてとは明らかである。

（3）なおことで parikalpita-rūpa が parikalpita-svabhāva と同樣 bahuvrīhi の合 成語であるてとは言うまでもない。

（4）なおてのほか，一般的に言つて，再歸代名詞としての ātman も吾々が今とてで 問題としている「體」と同じ意味をあらわしていると言つてょいであろら。 
以上を以て，

(a) parikalpita-svabhāva の svabhāva は，「性」としてではなく「體」とし て理解さるべきであるということ，

(b) ここでいら「體」とは，英語で言えば an animal in the form of a cow といら交脈中の form によつてあらわされる概念であり, 梵語で言えば go-rūpa-paśu, gavâtmaka-paśu という文脈中の rūpa 或は ātman によ つてあらわされる概念であるといらとと，

(c) svabhāvaという語にてのような意味をもたせることはsvabhāvaという語 の用法として決して無理なものではなく，安慧釋自身の中にも svabhāva $=$ rūpa, svabhāva $=\bar{a}$ tman の用例は容易に見出し得るといらとと，

の三點をほぼ明らかになし得たものと信ずる。なお念のため，ててで筆者は svabhāva を如何に和譯すべきかということを問題としているのではない。筆者が問 題としているのは, parikalpita-svabhāva といら術語の中での svabhāva とい う語の概念規定である。そして筆者が學界の墸賢に呚示を乞わんとするとてろは， svabhāva をてのように概念規定した場合, 唯識關係文獻中にあらわれる三性に 關する議論がすべて支障なく理解せられ得るかどうかといらてとである。はじめ に述べたように，筆者の考察は三十頌並にこれに對する安慧釋の範圍を出でない からである。

（本稿は昭和 42 年度文部省科學研究費による總合研究「佛敉受容の諸形態關する歷史 的研究」を分擔した際の研究成果の一部である。) 